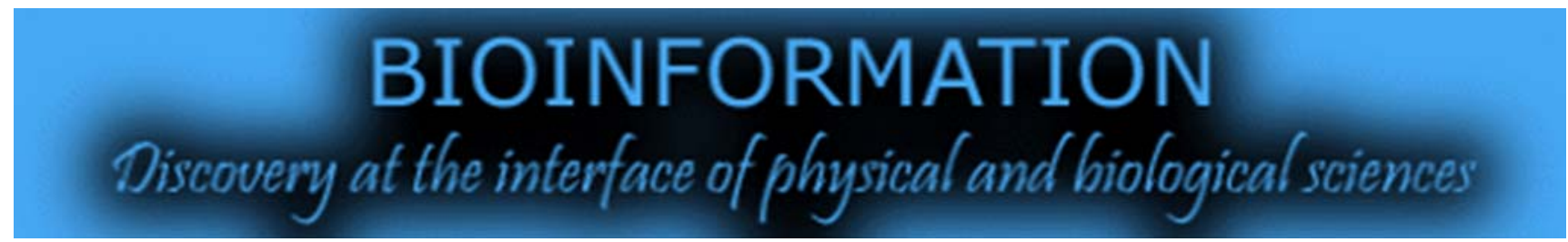

open access

www.bioinformation.net

Database

Volume 8(1)

\title{
BiodEnz:A database of biodegrading enzymes
}

\author{
Shobana Sugumar ${ }^{*}$, Berla Thangam ${ }^{2}$
}

1SRM University, School of Bio-engineering, Department of Bioinformatics, SRM Nagar, Kattankulathur,603203, Kancheepuram District, Tamil Nadu; ${ }^{2}$ SRM University, School of Bio-engineering, Department of Biotechnology, SRM Nagar, Kattankulathur603203, Kancheepuram District, Tamil Nadu; Shobana - E mail: ksemaa@gmail.com; phone: 9841988577; *Corresponding author

Received May 01, 2011; Accepted Jully 05, 2011; Published January 06, 2012

\begin{abstract}
:
Azo dyes, which re characterized by azo bonds, are a predominant class of colorants used in tattooing, cosmetics, foods, textile and consumer products. Laccases (EC 1.10.3.2), lignin peroxidases (EC_1.11.1.14)_, Azo reductases (EC 1.7.1.6) of different micro organisms are mainly useful for the development of biodegradation systems as they catalyse reductive cleavage of azo groups $(-\mathrm{N}=\mathrm{N}-)$. Laccases have very broad substrate specificity with respect to the electron donor and is capable of oxidizing phenols and aromatic amines. Azoreductase belongs to the family of oxidoreductases, acting on other nitrogenous compounds as donors with $\mathrm{NAD}+$ or NADP+ as acceptor. Lignin peroxidase enzymes are highly non-specific and are well reported to decolourize various dyes We have developed BiodEnz database by collecting information like strains that produce particular enzymes, azo dyes that are degraded, substrate specificity, molecular weight, the optimum temperature and $\mathrm{pH}$, sequence data of the above enzymes ,as the most effective inoculants used for bioremediation are able to degrade dyes over a broad concentration range, tolerate a range of environmental conditions of temperature, $\mathrm{pH}$, and activity of the enzymes. The database can be searched by using a user friendly web interface.
\end{abstract}

Keywords: Azodyes, azolinkages, bioaugmentation, biodegradation, enzyme specificity

Availability: http://www.biodenzdatabase.in

Background:

Azo dyes which represent about one-half of all dyes in common use are widely used by the textile, leather, cosmetics, food coloring and paper production industries. They are considered recalcitrant xenobiotic compounds due to the presence of a nitrogen double bond $(-\mathrm{N}=\mathrm{N}-)$ bond and other groups (i.e. sulfonic group) that are not easily biodegraded. The annual world production of azodyes is estimated to be around one million tons [1] .During the dyeing process, approximately 10$15 \%$ of the used dye is released into wastewater Treatment of dye-contaminated wastewater discharged from the textile and ISSN 0973-2063 (online) 0973-8894 (print) Bioinformation 8(1):040- 042 (2012) other dye-stuff industries is necessary to prevent contamination of soil and surface and ground water. Biological methods are generally considered eco friendly as they can lead to mineralization of organic pollutants effectively at very low cost [1]. Azodyes are recalcitrant to biodegradation due to their complex structures and xenobiotic nature, and typically require an anaerobic-aerobic process to achieve complete degradation. Bioremediation of azo dyes in textile waste effluents by bacteria or fungi is a very promising area of study because of the relatively low expense involved.Bioremediation includes biodegradation and biotransformation, with a goal to 461

(c) 2012 Biomedical Informatics 
mineralize hazardous contaminants in the environment. This is fulfilled by the azodye degrading enzymes like laccases,azoreductases, lignin peroxidases and some more which are vastly available in the variety of micro organisms like fungi, algae, bacteria. Bioaugmentation of the wastewater with highly effective strains provides a much more reliable process in which the process manager can use bacterial strains that target particular dye chemicals and metabolites to achieve complete mineralization. The most effective inoculants are able to degrade dyes over a broad concentration range,tolerate a range of environmental conditions of temperature, $\mathrm{pH}$, and salinity. Laccases are usually known as benzenediol: oxygen oxidoreductase. They belong to the class of blue oxidases.Their molecular mass ranges from 60 to $85 \mathrm{kDa}$ [2].Laccases are involved in the biodegradation of lignins, which constitute the main noncarbohydrate component in wood and are among the most abundant groups of biopolymers in the biosphere. A great number of white-rot fungi have been reported to produce the lignin-degrading enzymes laccase, lignin peroxidases, and manganese peroxidases, or at least one of these enzymes [3]. Azoreductase catalyzes the reductive cleavage of azo linkages in benzidine based dyes and other compounds containing an azo bond to produce aromatic amines.many bacterial strains possess many unspecific cytoplasmic enzymes which act as azoreductases. Azo reductases have been detected in liver cells and several anaerobic bacteria. It is studied that when azodye is incubated in oxygen free buffer with NADH as a source of reduction equivalents, a slow decolorization is noted Lignin peroxidase is a classical hemeprotein peroxidase containing heme in the active site with molecular weight between 38 and $47 \mathrm{KDa}$ [4]. Due to its high redox potential, LiP is able to directly oxidize non-phenolic lignin units. A characteristic of $\mathrm{LiP}$, which is also shared by non-ligninolytic peroxidases, is its relative unspecificity for substrates such as phenolic compounds and dyes.

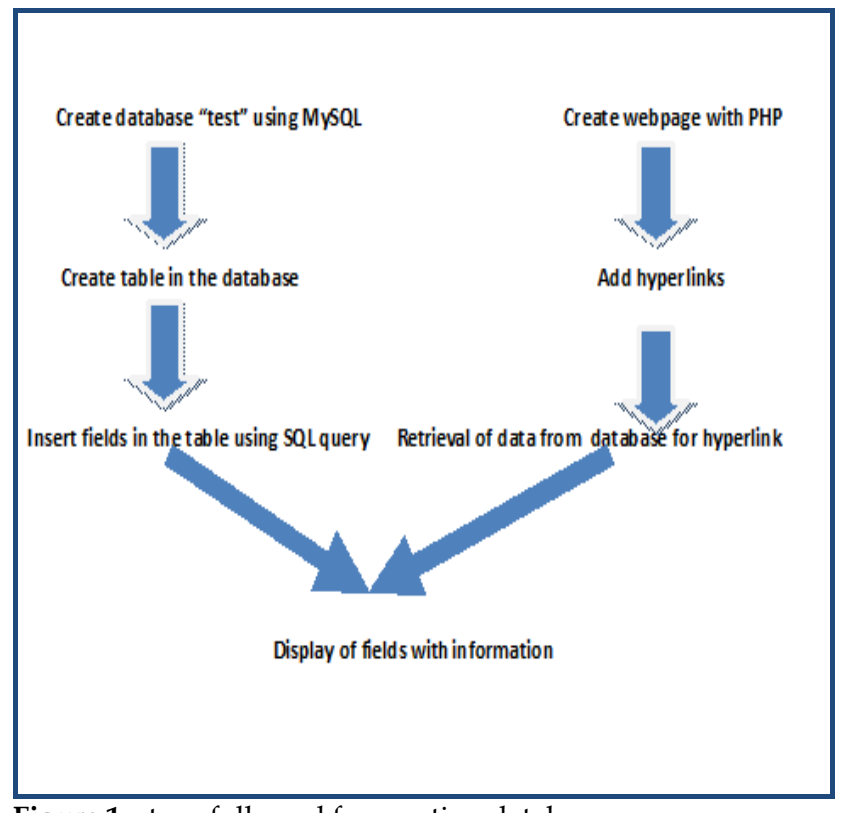

Figure 1: steps followed for creating database

ISSN 0973-2063 (online) 0973-8894 (print)

Bioinformation 8(1): 040-042 (2012)
Methodology:

Data collection \& curation:

A literature search was done using PubMed and the journals like ScienceDirect [9], Springerlink [10]. From that all the available information is retrieved till date. Search terms included azo dye degrading enzymes Laccase, Lignin peroxidase and Azoreductase. The data has also been collected form the database Brenda (an enzyme database). Nucleotide sequences are collected from NCBI [5] database and PDB ids are retrived from the Protein Data Bank [6]. All the information has been curated manually.

\section{Database structure:}

The entries of our 'BiodEnz' database are generated from a text mining of hundreds of published articles. Our current database contains 234 entries of the micro organisms like bacteria, fungi and algae and their strains containing the azo dye degrading enzymes laccases, lignin peroxidases and azoreductases. The data base has separate sections for each enzyme. The information included the organism or strain in which the particular enzyme is available, concentration of dye the enzyme decolorizes, name of azodyes that are degraded or decolorized, percentage of decolorization, time taken by the organism to decolorize, molecular weight of the particular enzyme, optimum temperature and $\mathrm{pH}$ for that enzyme, enzyme specificity, electron donors, inhibitors, substrates, sequences, accession number of the organism is given from NCBI, and PDB ID from PDB.

Development \& website structure:

The 'BiodEnz' database is developed using MySQL [7] a relational database management system that serves as the backend for storing data. APACHE 2.2 (Apache HTTP Server) is used as the web server and PHP5 (Hypertext preprocessor) [8] a widely used scripting language driven by Zend engine is used as the web interface. For the process of database creation in the PHP admin, the MySQL client version: 5.0.24a is used. The localhost of Server version: 5.0.24a, Protocol version: 10, Server: localhost via TCP/IP is used for the database creation. The local host for the process is php Myadmin of 2.9.0 as shown in the (Figure 1).

\section{Utility:}

BiodEnz database contains the detailed information about all the micro organisms ( \& their strains) such as bacteria, fungi and algae that contain the azo dye degrading enzymes, and also the properties of the lacasses, azoreductases, and lignin peroxidases in those organisms like specificity of the enzymes, molecular weight, percentage of decolorization, enzyme activity, the optimum temperature and $\mathrm{pH}$ required for the enzyme to degrade the dyes. Our current database includes 89 entries of micro organisms for laccases, 88 entries of micro organisms for azoreductases and 57 entries of micro organisms for lignin peroxidases from various literatures and journals from1990 to 2010. An activated sludge with culture of selected microbial strains is effective to degrade textile dyes in water. So our database provides a valuable information to perform bioaugmentation which is a biological cost effective method to convert the highly toxic and colourful dyes to 41 
colourless,nontoxic substances, so that eco reserves are preserved. The sequences of the enzymes, Accession numbers, pdb ids are also included for further research about azodyes.

\section{Further development:}

The current database contains all the data about the three enzymes azoreductases, lignin peroxidase and laccases. In future we plan to add data about other azodye degrading enzymes and to update and improve the information from time to time from the sources.

\section{References:}

[1] Pandey A et al. International Biodeterioration $\mathcal{E}$ Biodegradation.2007 59:73
[2] Dey S et al. Appl Environ Microbiol. 1994 60: 4216 [PMID: 7527628]

[3] Stolz A, Applied Microbiology and Biotechnology 2001 56: 69[PMID: 11499949]

[4] Wesenberg D et al. Biotechnol.Advan.2003 22: 161 [PMID: 14623049]

[5] http://www.ncbi.nlm.nih.gov/nucleotide/

[6] http://www.pdb.org

[7] http://www.mysql.com

[8] http://www.php.net

[9] http://www.sciencedirect.com

[10] http://www.springerlink.com

Citation: Sugumar \& Thangam, Bioinformation 8(1):040- 042 (2012) License statement: This is an open-access article, which permits unrestricted use, distribution, and reproduction in any medium, for non-commercial purposes, provided the original author and source are credited. 